\title{
Pengaruh Temperatur Terhadap Kecepatan Pertumbuhan Kacang Tolo (Vigna sp.)
}

\author{
Vivin Andriani ${ }^{1}$ dan Ratna Karmila ${ }^{2}$ \\ ${ }^{1}$ Staf Pengajar Prodi Biologi FMIPA Universitas PGRI Adi Buana Surabaya \\ ${ }^{2}$ Staf Pengajar Prodi Biologi Universitas Al-Ghifari Bandung \\ Email: v.andriani@unipasby.ac.id
}

\begin{abstract}
ABSTRAK
Pertumbuhan tumbuhan sangat dipengaruhi suhu. Setiap varietas memiliki suhu tertentu untuk pada tahap daur hidup. Pada suhu dibawh minimum beberapa variates tidak akan bisa tumbuh dan berkembang. Tanaman Vigna sp. Termasuk kedalam jenis sayuran yang dapat dikembangkan di Indonesia, karena dapat meningkatkan perekonomian. Kacang tolo diolah sebagai sayur dan camilan. Tujuan Penelitian ini adalah untuk mengetahui apakah temperatur berpengaruh terhadap pertumbuhan kacang tolo (Vigna sp.). Penelitian ini menggunakan Rancangan Acak Lengkap (RAL) dengan 3 perlakuan ruangan, oven dan refrigerator. Parameter yang diambil data adalah pertambahan panjang hipokotil. Hasil penelitian menunjukkan bahwa pertambahan panjang hipokotil setiap perlakua berpengaruh signifikan pada pertambahan panjang hipokotil. Temperatur sangat mempengaruhi pertumbuhan dan perkembangan tanaman kacang tolo (Vigna sp.). Pertumbuhan tanaman akan optimal pada suhu optimum pertumbuhannya. Adanya kenaikan atau penurunan suhu lingkungan akan mempengaruhi pertumbuhan dan perkmembangannya.
\end{abstract}

Kata Kunci: Temperatur, Pertumbuhan, Vigna sp.

\section{Pendahuluan}

Pertumbuhan tanaman sangat dipengaruhi suhu. Setiap spesies ataupun varietas tanaman memiliki rentan terhadap suhu tertentu, yaitu suhu minimum, optimum dan maksimum. Jika lingkungan suhu minimum maka tanaman tidak akan tumbuh. Suhu optimum akan menyebabkan laju pertumbuhan menjadi tinggi, sedangkan suhu diatas maksimum akan mengakibatkan tanaman tidak mengalami pertumbuhan dan tanaman akan mati jika tidak dapat beradaptasi dengan cekaman (Salisbury dan Ross, 1995).

Seperti organisme yang lain, tumbuhan yang terkena panas berlebihan membahayakan dan bahkan membunuh tumbuhan dengan mendenaturasikan enzim yang berperan dalam metabolisme, sehingga proses metabolisme akan rusak. Cuaca yang panas dan kering juga cenderung mendehidrasi banyak tumbuhan, penutupan stomata sebagai respon terhadap stres ini menghemat air namun 
mengorbankan pendinginan evaporatif. Dilema ini merupakan salah satu alas an mengapa hari-hari yang sangat panas dan kering dapat mematikan sebagian besar tumbuhan. Sebagian besar tumbuhan memiliki respons pendukung yang memungkinkan tumbuhan sintas dari stress panas. Di atas suhu tertentu, sekitar $40^{\circ} \mathrm{C}$ bagi sebagian besar tumbuhan di wilayah beriklim sedang, sel-selnya mulai mensintesis heat shock protein, yang membantu melindungi protein-protein lain dari stress panas. Masalah yang dihadapi tumbuhan ketika suhu lingkungan turun adalah perubahan fluiditas membrane sel. Jika membran mendingin di bawah titik kritis, fluiditasnya hilang karena lipid terkunci menjadi struktur-struktur kristal. Ini mengubah transpor zat terlarut menyeberangi membran dan juga member pengaruh buruk pada fungsi-fungsi protein membran (Campbell, et al., 2008).

Tanaman kacang tolo (Vigna sp.) adalah sala satu jenis sayuran yang digemari di Indonesia. Tanaman ini memiliki nilai ekonomi yang tinggi, sehingga perlu dikembangkan. Kacang tolo dapat dapat diolah menjadi sayur dan camilan. Kacang ini mengandung mineral, vitamin, protein, karbohidrat, Lemak dan air. Dari kandungan tersebut kacang tolo dapat digunakan untuk peningkatan gizi pada masyarakat sebagai sumber protein nabati. Selain berfungsi untuk masyarakat juga berfungsi pada bidang pertanian karena dapat menyuburkan tanah. Bintil akar yang pada kacang tolo terdapat bakteri Rhizobium sp. Bakteri tersebut menangkap nitrogen bebas dari udaradan merubahnya sesuai yang dibutuhkan tanaman (Haryanto, 2003).

\section{Metode Penelitian}

Penelitian ini menggunakan Rancangan Acak Lengkap (RAL). Sampel pada penelitian ini yaitu tanaman Vigna sp. Yang di beri 3 perlakuan yaitu suhu ruang, oven dan refrigerator dan dilakukan pengulangan sebanyak 3 kali.

\section{Hasil Dan Pembahasan}

Data hasil pengamatan pada tanaman kacang tolo (Vigna sp) yang ditempatkan pada ruangan, oven dan refrigerator. Hasil pengamatan ditunjukkan pada gambar di bawah ini. 


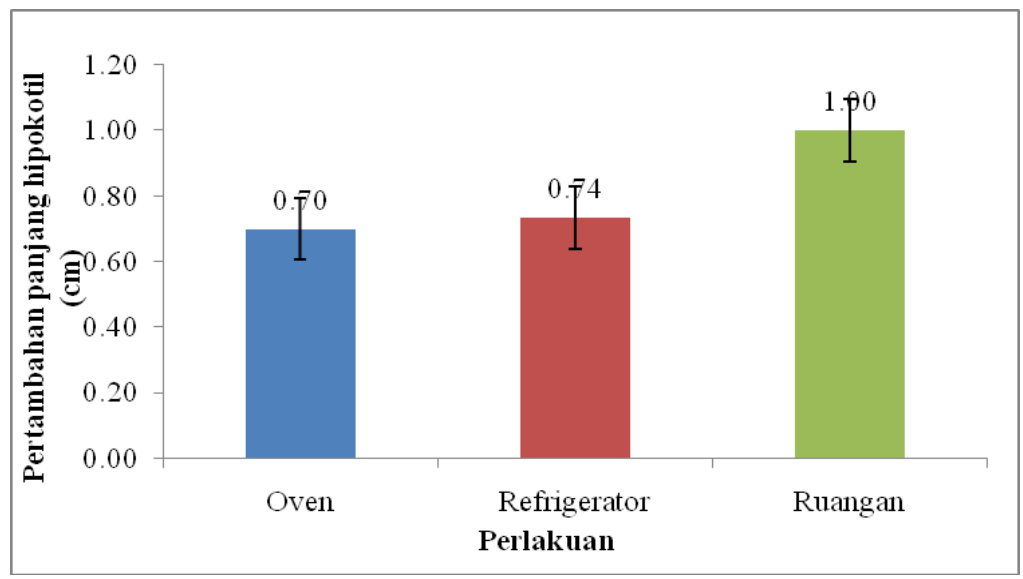

Gambar 1 Pertambahan Panjang Hipokotil Pada Setiap Perlakuan

Berdasarkan pengamatan tanaman seperti pada gambar 1 terlihat bahwa tanaman yang diletakkan pada suhu ruangan memiliki pertambahan panjang yang lebih tinggi dibandingkan dengan tanaman yang diletakkan ditempat dengan suhu tinggi dan suhu rendah.

Tanaman hanya bisa tumbuh dan berkembang dengan baik pada suhu optimum. Pada suhu minimum tanaman akan terganggu pertumbuhanya, sedangkan pada suhu maksimum pertumbuhan akan terganggu dan juga dapat mengakibatkan tumbuhan mati. Pada lingkungan dengan suhu yang lembab mengakibatkan tumbuhan banyak menyerap air dan penguapannya berkurang. Pada situasi seperti itu dapat mendukung proses pemanjangan sel (Salisbury dan Ross, 1995).
Pada suhu berkisar $21^{\circ} \mathrm{C}$ proses fotosintesis akan berlanggsung dengan optimal. Kondisi seperti itu proses pembentukan glukosa akan berjalan dengan baik. Sehingga fotosintat hasil dari proses fotosintesis dapat didistribusikan dengan baik keseluruh tubuh tanaman. nAmun sebaliknya jika suhu rendah energi yang dihasilkan relatif rendah. Seperti pendapat Taiz \& Zieger (2002), temperatur mempengaruhi semua reaksi biokimia fotosintesis. Pada suhu rendah, fotosintesis dibatasi oleh ketersediaan fosfat di kloroplas. Lambatnya fotosintesis akan mempengaruhi sintesisi pati dan sukrosa pada tanaman. Laju fotosintesis tertinggi pada suhu optimal. Ketika suhu optimal terlampaui, laju fotosintesis kembali menurun. suhu optimal adalah titik dimana kemampuan berbagai tahap dalam fotosintesis berjalan optimal dan seimbang. 
Suhu yang tinggi menyebabkan peningkatan respirasi di atas laju fotosintesis. Ini berarti bahwa produk fotosintesis digunakan lebih cepat daripada yang sedang diproduksi.

Untuk pertumbuhan, fotosintesis yang terjadi harus lebih besar daripada respirasi (Anonymous, 1998). Pada tanaman yang ditempatkan di dalam oven, daun tanaman menggulung keatas. Suhu akan mempengaruhi laju respirasinya, dimana laju respirasi lebih besar daripada laju fotosintesisnya sehingga pertumbuhannya terhambat. Temperatur yang meningkat mempengaruhi kecepatan reaksi, sehingga reaksi akan meningkat karena pada molekul atom memiliki suatu energi yang tinggi dan memiliki tingkat berpindah yang cenderung tinggi. Peningkatan temperatur akan mempengaruhi proses berlangsungnya denaturasi dan mempengaruhi aktivitas enzim. Kejadian tersebut disebabkan rantai protein tidak terjadi pelipatan setelah proses terputusnya ikatan yang bersifat lemah, sehingga menyebabkan menurunnya kecepatan reksi.

Pada tanaman yang ditempatkan dalam refrigerator, memiliki morfologi yang kurang baik. Pada suhu rendah (refrigerator) daun tanaman terlihat pucat dan sedikit menggulung ke atas. Berubahnya bentuk tersebut disebabkan karena pada suhu rendah, enzim mengalami kerusakan tetapi tidak maksimal sehingga aktivitas kerjanya akan berkurang (Gaman dan Sherrington, 1994). Pada penelitian Weber dan Jorensen (2000) mengungkapkan bahwa pada tanaman Pinus panderosa muncul semai mengalami peninkatan hingga $50 \%$ saat diberi perlakuan suhu rendah antara $10-15^{\circ} \mathrm{C}$. Hal ini menunjukkan bahwa pada temperature rendah masih terjadi metabolism tetapi kerja enzim pada proses tersebut sangat lambat,sehingga pertumbuhan juga lambat.

Perubahan temperatur juga akan berpengaruh terhadap penyerapan unsur hara. Suhu tanah mempengaruhi kandungan air dalam tanah. Jika suhu tanah naik maka kandungan air akan berkurang yang mengakibatkan unsur hara dan mineral tidak dapat terserap secara maksimal dan sebaliknya apabila suhu tanah rendah kandungan air dalam tanah akan meningkat dan dapat mengakibatkan pengkristalan saat kondisi lingkungan ekstrem. Kondisi seperti itu akan mengakibatkan proses repirasi berlangsing tidak maksimal sehingga terjadi translokasi pada tanaman menjadi lebih lama. Apabila proses translasi 


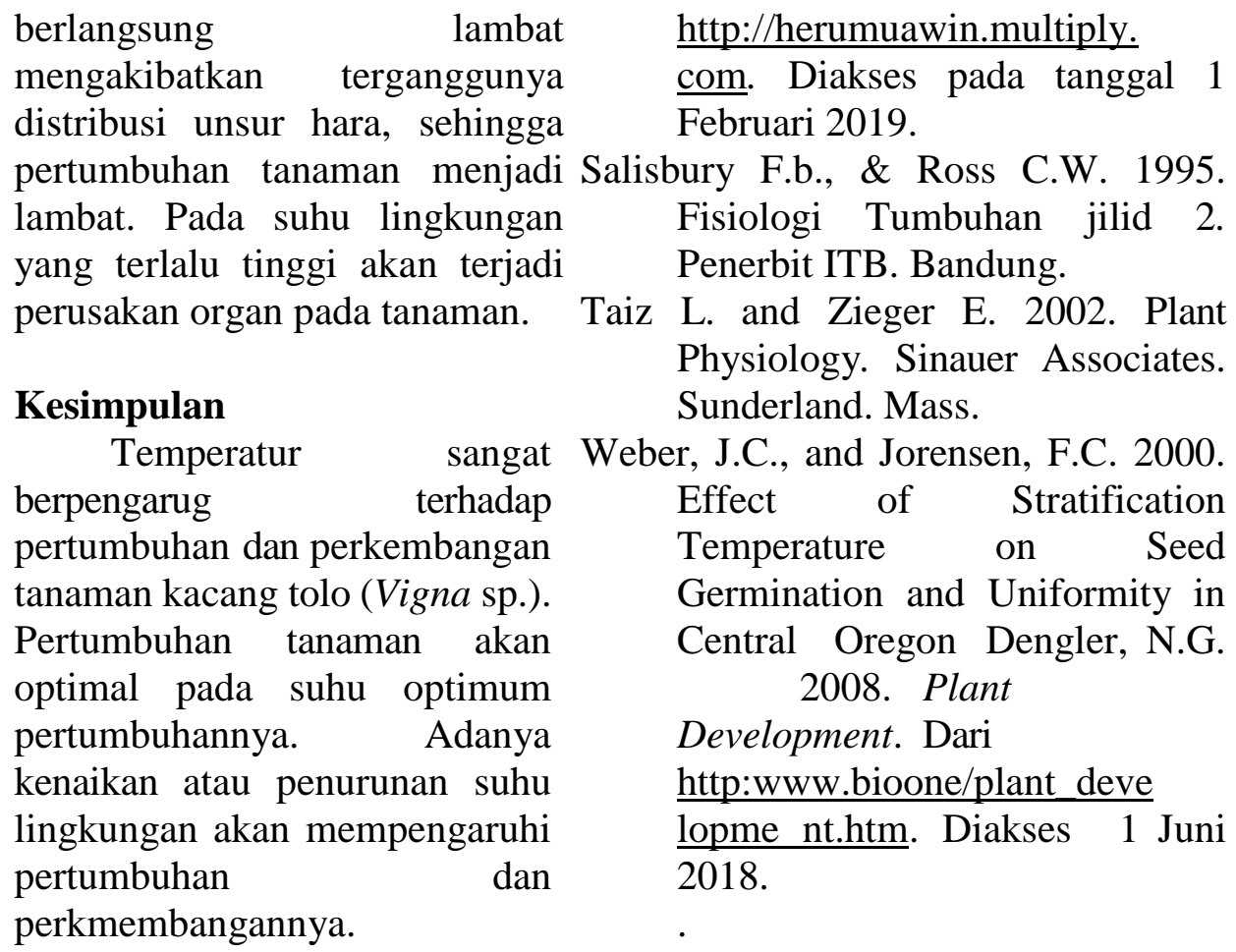

\section{Daftar Pustaka}

Anonymous. 1998. Environmental Factors That Affect Plant Growth. The University of Arizona. Campbell, N.A., Reece J.B., Urry L.A., Cain M.L., Wasserman S.A., Minorsky P.V., \& Jackson R.B. 2008. Biologi Edisi Kedelapan Jilid 2. Erlangga. Jakarta.

Gaman, P.M \& K.B. Sherrington. (1994). Ilmu Pangan, Pengantar Ilmu Pangan, Nutrisi dan Mikrobiologi. Universitas Gadjah Mada press. Yogyakarta.

Lambers H, Chapin F.S, \& Pons T.L. 2008. Plant Physiological Ecology $2^{\text {nd }}$ Edition. Springer. New Yok. Muawin, Heru. 2008. Faktor Lingkungan dalam Pertumbuhan Tanaman. 